УДК 550.73

\title{
СОРБЦИОННЫЕ СВОЙСТВА ТОРФА И ГУМИНОВЫХ КИСЛОТ ПО ОТНОШЕНИЮ К БЛАГОРОДНЫМ МЕТАЛЛАМ
}

\author{
() В.И. Радомская ${ }^{\prime *}$, Л.М. Павлова ${ }^{1}$, Л.П. Носкова ${ }^{1}$, В.Ю. Котельников ${ }^{2}$, В.В. Иванов ${ }^{3}$, \\ А.В. Поселюжная ${ }^{3}$ \\ ${ }^{1}$ Институт геологии и природопользования ДВО РАН, пер. Релочный,1, \\ Благовещенск, 67500 (Россия), e-mail:radomskaya@ascnet.ru \\ ${ }^{2} Э$ эспертно-криминалистический центр УМВД России по Амурской области, \\ Батарейная, 30а, Благовещенск, 67500 (Россия) \\ ${ }^{3}$ Дальневосточный геологический институт ДВО РАН, пр. 100 лет \\ Владивостоку, 159, Владивосток, 690022 (Россия)
}

\begin{abstract}
Выполнены экспериментальные исследования сорбции золота и палладия торфом и гуминовыми кислотами. Результаты исследований показали возможность извлечения благородных металлов природными сорбентами. При взаимодействии растворов золота с поверхностью торфа и гуминовых кислот, палладия с торфом происходит восстановление благородных металлов с образованием наночастиц на поверхности. Взаимодействие гуминовых кислот с растворами палладия останавливается на стадии сорбции.

Ключевые слова: торф, гуминовые кислоты, сорбция, восстановление, наночастицы золота, палладия.

Работа выполнена при поддержке гранта Президиума ДВО РАН 12-III-A-08-142.
\end{abstract}

\section{Введение}

Сорбционные методы нашли применение в технологии извлечения и концентрирования благородных металлов из вторичного сырья, в том числе из солянокислых растворов. Однако большинство из предлагаемых для практического применения сорбентов малодоступны. В этой связи актуален поиск и исследование доступных и недорогих сорбентов, обладающих высокой сорбционной емкостью и селективностью по отношению к благородным металлам. Особый интерес представляют биосорбенты, в частности торф и гуминовые кислоты. Сорбционные свойства торфа определяются развитой пористой структурой и наличием большого разнообразия функциональных групп. Наиболее активными составляющими ископаемых топлив низкой степени углефикации являются гуминовые вещества, участвующие в реакциях ион-

Радомская Валентина Ивановна - ведущий научный сотрудник лаборатории биогеохимии, e-mail: radomskaya@ascnet.ru

Павлова Людмила Михайловна - заведующая лабораторией биогеохимии, e-mail: pav@ ascnet.ru Носкова Лидия Петровна - старший научный сотрудник лаборатории палеогеографии и природопользования, e-mail: noskova@ ascnet.ru Котельников Валерий Юрьевич - главный эксперт отдела физико-химических экспертиз, e-mail: kotelnikov.valery@gmail.com

Иванов Владимир Викторович - заведующий лабораторией микро- и наноисследований, e-mail: d159327@yandex.ru

Поселюжная Анна Владимировна - старший инженер лаборатории микро- и наноисследований, e-mail: anna_ivv@mail.ru ного обмена, переноса электрона, комплексообразования, в донорноакцепторных, гидрофобных и сорбционных взаимодействиях $[1,2]$. В работах по изучению сорбции металлов показано, что гуминовые кислоты обладают высокой сорбционной емкостью по отношению к тяжелым металлам и радионуклидам $[3,4]$. Приуроченность аномальных количеств золота к торфам в Верхнем Приамурье уже отмечалась в литературе [5]. Однако работы по сорбции благородных металлов на органических природных сорбентах, в частности на гуминовых кислотах, немногочисленны, и до настоящего времени механизм взаимодействия гуминовых кислот с благородными металлами остается дискуссионным.

\footnotetext{
* Автор, с которым следует вести переписку.
} 
Цель выполненных исследований - изучение процессов концентрирования хлоридных комплексов палладия и золота полимерной матрицей торфа и ее наиболее активного компонента - гуминовых кислот, и установление особенностей взаимодействия с ионами золота (III) и палладия (II). Практическая значимость выполненных исследований состоит в оценке потенциальных возможностей природных биосорбентов в процессах извлечения благородных металлов.

\section{Экспериментальная часть}

Была изучена сорбция палладия (II) и золота (III) торфом и выделенными из него препаратами обеззоленных гуминовых кислот. В работе использован низинный осоковый торф месторождения Егорьевское-2 (Амурская область). Ботанический состав торфа: осока волосистоплодная - 35\%, вейник Лангсдорфа $10 \%$, хвощ болотный - 10\%, зеленые мхи $10 \%$, осока псевдокурайская - 5\%, пушица рыжеватая - 5\%, пушица влагалищная - 5\%, пушица узколистная - 5\%, хвощ топяной - 5\%. Единично встречались сфагнум восточный, ирис, калужница карликовая, пузырчатка, сабельник болотный.

Гуминовые кислоты из воздушно-сухой навески измельченного торфа получали, предварительно удалив экстракцией гексаном битумы, содержание которых в органическом веществе исследуемого образца составляло 4,7\%. Дебитуминизированный торф троекратно обрабатывали 0,1 М раствором гидроксида натрия, отделяя негидролизуемый остаток центрифугированием. Осаждали гуминовые кислоты (ГК) коагуляцией при подкислении 5\%-ным раствором соляной кислоты до $\mathrm{pH}$ 1,0-1,5. Все органические вещества, оставшиеся в кислом растворе после выделения ГК, рассматривали как фульвокислоты. ГК отделяли центрифугированием, переносили на фильтр, промывали дистиллированной водой до нейтрального значения pН и высушивали в вакуумном сушильном шкафу при температуре $60-70{ }^{\circ} \mathrm{C}$ до постоянной массы. Содержание гуминовых веществ в торфе составляло 66\%, негидролизуемого остатка (НОС) - 34\%. В составе гуминовых веществ преобладали гуминовые кислоты, доля которых в 3-4 раза выше, чем фульвокислот. Содержание золы в выделенных ГК составило 18,75\%. Так как минеральные компоненты, как правило, связаны с карбоксильными и гидроксильными группами органического вещества, была проведена деминерализация полученных препаратов ГК 5\%-ным раствором плавиковой кислоты на водяной бане. Осадок обеззоленных ГК многократно промывали водой и высушивали на воздухе.

Элементный анализ сорбентов определяли на анализаторе Vario EL Cube фирмы Elementar. Количество фенольных гидроксилов и карбоксильных групп устанавливали Са-ацетатным и баритовым методами [6]. Характеристика объектов исследования приведены в таблице 1.

Исходные растворы палладия (II) и золота (III) с концентрацией 1000 мг/мл в 1 М НСl готовили растворением точной навески палладия либо золота в царской водке с последующим выпариванием раствора до влажных солей, обработкой концентрированной $\mathrm{HCl}$ и повторным выпариванием и растворением остатка в $1 \mathrm{M} \mathrm{HCl}$. Из исходных растворов в день проведения эксперимента разбавлением дистиллированной водой готовили рабочие растворы, содержащие различные количества $\mathrm{Pd}$ (II) и Au(III).

Сорбцию палладия (II) и золота (III) изучали в статистических условиях при соотношении объема водного раствора и сорбента от 200 до 500 мл/г.

Исследование сорбции золота (III) и палладия (II) ГК в щелочной среде проводили аналогично экспериментам в кислой среде, добавляя в щелочной раствор ГК алликвоту сорбируемого благородного металла. После сорбции перед определением равновесных концентраций металла в растворах пробы доводили до рН 1 и центрифугировали для полного осаждения ГК.

Содержание палладия в исходных и равновесных водных растворах определяли с помощью вольтамперометрического анализатора ТА-4. Содержание золота определяли атомно-абсорбционным методом на спектрофотометре 1 класса «Хитачи»-180-50. По разности между исходной концентрацией и концентрацией металла в растворе после сорбции рассчитывали величину адсорбции (А), выраженную в миллиграммах на 1 г сорбента.

Таблица 1. Характеристика объектов исследования

\begin{tabular}{c|c|c|c|c|c|c|c|c|c|c}
\hline \multirow{2}{*}{$\begin{array}{c}\text { Cop- } \\
\text { бент }\end{array}$} & \multicolumn{2}{|c|}{ Технические параметры, \% } & \multicolumn{4}{c|}{ Элементный состав, \% на daf } & \multicolumn{3}{|c}{ Функциональные группы, } \\
& $\mathrm{W}^{a}$ & $\mathrm{~A}^{d}$ & $\mathrm{~V}^{\text {daf }}$ & $\mathrm{C}$ & $\mathrm{H}$ & $\mathrm{N}$ & $\mathrm{S}$ & $\mathrm{O}$ & $-\mathrm{COOH}$ & $-\mathrm{OH}_{\text {фен }}$ \\
\hline Торф & 9,30 & 35,57 & 70,26 & 59,77 & 7,31 & 4,35 & 1,12 & 27,45 & 0,85 & 5,01 \\
ГК & 4,67 & 0,24 & - & 58,29 & 5,50 & 3,49 & 0,74 & 31,98 & 2,57 & 4,41 \\
\hline
\end{tabular}


ИК-спектроскопические исследования проводили на ИК Фурье-спектрометре «Spectrum One», который автоматически регистрирует инфракрасные спектры пропускания исследуемых проб в диапазоне волновых чисел 4000-500 $\mathrm{cm}^{-1}$. Разрешение спектра $2 \mathrm{~cm}^{-1}$.

Изучение ультраструктуры поверхности исследуемых образцов и зондовый микроанализ выполнены на сканирующем электронном микроскопе JSM-6490LV с ЭДС INCA Energy, X-max и ВДС INCA Wave. Частицы торфа и гуминовых кислот перед их напылением хромом в вакууме были помещены на двухсторонний углеродный скотч, прикрепленный на столбик из технического алюминия.

\section{Результаты и обсуждение}

Для уточнения полученных ранее предварительных данных о механизмах связывания ионов $\mathrm{Pd}$ (II) и $\mathrm{Au}$ (III) [7-8] были проведены дополнительные исследования кинетики сорбции ионов золота и палладия на торф и выделенные из него ГК и установление влияния РН на их сорбционные свойства. Два основных фактора определяют сорбцию органических сорбентов по отношению к ионам благородных металлов: это количество и состояние функциональных групп сорбента и соотношение химических форм ионов металлов в растворе.

Ионные состояния палладия в солянокислых растворах подробно изучены в работах [9-11]. Химия палладия в солянокислых растворах сложна. Для него характерно многообразие химических форм, легкость перехода из одной формы в другую, склонность хлоркомплексов к гидролизу и полимеризации. В водных и солянокислых растворах палладия протекают, часто параллельно, реакции акватации, полимеризации, изомеризации, скорость и полнота которых существенно зависят от исходной химической формы, температуры, солевого фона, времени выдержки раствора, концентрации металла, хлор-иона и др. Наиболее устойчивой формой палладия в солянокислых растворах является $\left[\mathrm{PdCl}_{4}\right]^{2-}$. В зависимости от концентрации ионов $\mathrm{H}^{+}$и $\mathrm{Cl}^{-}$в растворах могут образовываться комплексы состава $\left[\mathrm{Pd}\left(\mathrm{H}_{2} \mathrm{O}\right)_{\mathrm{n}} \mathrm{Cl}_{4-\mathrm{n}}\right]^{\mathrm{n}-2}$, где $\mathrm{n}$ может изменяться от 0 до 3.

$$
\left[\mathrm{PdCl}_{4}\right]^{2-}+\mathrm{H}_{2} \mathrm{O} \leftrightarrow\left[\mathrm{Pd}\left(\mathrm{H}_{2} \mathrm{O}\right) \mathrm{Cl}_{3}\right]^{-}+\mathrm{Cl}^{-}
$$

В солянокислой среде в диапазоне концентраций $\mathrm{Cl}^{-}$0,1-0,5 $\mathrm{M}$ существуют комплексы $\left[\mathrm{Pd}\left(\mathrm{H}_{2} \mathrm{O}\right) \mathrm{Cl}_{3}\right]$ и $\left[\mathrm{PdCl}_{4}\right]^{2-}$, при концентрации хлор-иона не меньше $1 \mathrm{M}$ доминирует ион $\left[\mathrm{PdCl}_{4}\right]^{2-}$.

Продукты, образующиеся при добавлении щелочи к раствору $\mathrm{H}_{2}\left[\mathrm{PdCl}_{4}\right]$, предположительно представляют собой полиядерные комплексы, содержащие $\mathrm{OH}^{-}$и $\mathrm{H}_{2} \mathrm{O}$ - лиганды $\left(\left[\mathrm{Pd}\left(\mathrm{H}_{2} \mathrm{O}\right)_{2} \mathrm{OH}\right]^{+}\right.$ и $\left.\left[\mathrm{Pd}\left(\mathrm{H}_{2} \mathrm{O}\right)_{2}(\mathrm{OH})_{2}\right]\right)$, либо являются коллоидными частицами гидроксида $\mathrm{Pd}(\mathrm{II})$. При дальнейшем увеличении $\mathrm{pH}$ образуются комплексы $[\mathrm{Pd}(\mathrm{OH})]^{+}\left[\mathrm{Pd}(\mathrm{OH})_{4}\right]^{2-}$, появлением которых объясняется растворение гидроокиси палладия в щелочах. Изучение растворимости гидроксида палладия (II) в хлоридных растворах показало, что при $\mathrm{pH}<3$ образуются анионные комплексы; при $\mathrm{pH}>3-4$ начинается образование полиядерных комплексов, а при рН >8 хлорид ионы во внутренней координационной сфере отсутствуют [9].

В сильнокислых хлоридных растворах ион золота (III) присутствует в виде хлорокомплексов золота (III) $\left[\mathrm{AuCl}_{4}\right]^{-}[12]$. В широком интервале концентраций $\mathrm{Au}$ (III) в растворах $\mathrm{HCl}$ существует гидратированный ион $\left[\mathrm{AuCl}_{4}\left(\mathrm{H}_{2} \mathrm{O}\right)_{2}\right]^{-}[13]$. Для реакции $\mathrm{AuCl}_{4}^{-}+\mathrm{H}_{2} \mathrm{O} \leftrightarrow \mathrm{AuCl}_{3} \mathrm{OH}^{-}+\mathrm{H}^{+}+\mathrm{Cl}^{-}$константа скорости гидролиза составляет $0,5 \cdot 10^{-2}$ сек $^{-1}$. Показано, что при рН 2,$25 ; 2,56 ; 2,71 ; 2,90$ и 3,11 гидролизовано соответственно 6,$45 ; 7,70 ; 8,52 ; 12,90$ и $23,30 \%$ Au (III). Установлено, что при концентрации $10^{-5}-10^{-4}$ г-ион/л Аu (III), $\geq 10^{-2}$ г-ион/л Сl и рН 2,6-4,2, все золото (III) находится в форме анионного комплекса.

Конечным продуктом гидролиза золотохлористоводородной кислоты является соединение $\mathrm{H}\left[\mathrm{Au}(\mathrm{OH})_{4}\right]$. Склонность к гидролизу солей золота (III) в водных растворах часто приводит к осаждению $\mathrm{AuOOH}$. Гидроокись золота растворяется в щелочах $\mathrm{AuOOH}+\mathrm{KOH}+\mathrm{H}_{2} \mathrm{O}=\mathrm{K}\left[\mathrm{Au}(\mathrm{OH})_{4}\right]$ [14].

Таким образом, доминирующими формами золота и палладия в сильнокислых растворах являются комплексы $\left[\mathrm{AuCl}_{4}\right]^{-}$и $\left[\mathrm{PdCl}_{4}\right]^{2-}$, тогда как в слабокислых растворах дополнительно образуются комплексы $\left[\mathrm{AuCl}_{3} \mathrm{OH}\right]^{-},\left[\mathrm{AuCl}_{4}\left(\mathrm{H}_{2} \mathrm{O}\right)_{2}\right]^{-},\left[\mathrm{Pd}\left(\mathrm{H}_{2} \mathrm{O}\right) \mathrm{Cl}_{3}\right]^{-},\left[\mathrm{Pd}\left(\mathrm{H}_{2} \mathrm{O}\right)_{2} \mathrm{OH}\right]^{+}$и $\left[\mathrm{Pd}\left(\mathrm{H}_{2} \mathrm{O}\right)_{2}(\mathrm{OH})_{2}\right]$.

Кроме гидролиза отпечаток на процесс сорбции торфом и выделенными из него ГК накладывает и наличие различных функциональных групп. Торф - это слабокислотный полифункциональный ионообменник, состоящий из разнообразных химических компонентов органической и неорганической природы. В него входят гидрофильные вещества (целлюлоза, гемицеллюлоза, лигнин, гуминовые вещества), гидрофобные составляющие (битумы, воска), а также минеральные и органоминеральные включения различной степени дисперсности. Поэтому диапазон представленных в торфе функциональных групп охватывает всю область значений рК - от 2 до 14. 
Гуминовые кислоты состоят из гидрофобного ароматического каркаса с большим содержанием функциональных групп. В структуре гумусовых кислот присутствует множество кислородсодержащих функциональных групп: карбоксильные группы, фенольные и спиртовые гидроксилы, карбонильные группы, хиноидные, лактонные и эфирные группировки, а также азотсодержащие функциональные группы [15]. По природе функциональных групп ГК, как сорбент, подобны слабокислотным карбоксильным катионитам. Из числа основных функциональных групп ГК можно выделить два типа: карбоксильные $\mathrm{COOH} \mathrm{и} \mathrm{фенольные} \mathrm{-OH,} \mathrm{их} \mathrm{основные} \mathrm{области} \mathrm{диссоциации} \mathrm{характеризуются} \mathrm{рК} \mathrm{3-5} \mathrm{и} \mathrm{8-9} \mathrm{соответствен-}$ но. При рН ниже 6 будут полностью диссоциированы сильнокислотные карбоксильные функциональные группы, а также карбоксильные группы средней силы [3]. В указанном диапазоне рН гуминовые кислоты представляют собой твердую фазу, а при более высоких рН наблюдается окрашивание растворов, что свидетельствует о частичном или полном растворении ГК. Переход ГК в водную фазу, вероятно, обусловлен усилением диссоциации кислотных функциональных групп при росте $\mathrm{pH}$, что приводит к появлению избыточного заряда на поверхности частиц гуминового полиэлектролита.

Таким образом, изотерма сорбции может быть неоднородной в диапазоне насыщения, как ГК, так и торфа ионами благородного металла и возможно наложение зависимостей, характеризующих сорбцию ионов металлов с участием функциональных групп разных типов.

Так как органические сорбенты, такие как торф, ГК имеют гидрофобный характер и нерастворимы в воде, то их взаимодействию предшествует диффузия ионов благородных металлов к твердому телу через окружающую его гидродинамическую пленку («пленочная» диффузия) и диффузия ионов к лигандным группам сорбента внутри пор («гелевая» диффузия). Как следует из рисунка 1, минимальная (практически нулевая) сорбция $\mathrm{Au}$ (III), Pd (II) из 0,05 M раствора $\mathrm{HCl}$ с рН 1,3 поверхностью торфа наблюдалась в течение 2 ч, ГК в течение первого часа. За 24 ч устанавливалось равновесие только в распределении Аи (III) между раствором и ГК, максимальная сорбция палладия достигалась за 36 чв для торфа и 48 ч для ГК.

Сравнение сорбционных возможностей органических сорбентов показало, что малозольные препараты гуминовых кислот обладают большей селективностью по отношению к благородным металлам, чем торф. Сорбционная емкость по палладию при данных условиях составила 11,7 и 6,3 мг/г для ГК и торфа соответственно. Для золота при рН 1,3 и времени сорбции 72 ч сорбционные емкости ГК и торфа были равны 32,5 и 22,2 мг/г. Таким образом, экспериментальные исследования показали, что золото имеет более высокое сродство к органическим сорбентам, чем палладий. Более низкое извлечение палладия (II) по сравнению с золотом (III) можно объяснить большей кинетической инертностью его хлоридных комплексов, особенно в слабокислых средах, что связано с присутствием нейтральных и заряженных аквакомплексов. Кроме того, для Рd в степени окисления +2 не характерно сродство к лигандам с донорными атомами кислорода [16]. В дальнейшем процесс сорбции проводили в течении 72 ч.

Были проведены исследования по определению влияния рН раствора на полноту сорбции палладия, золота гуминовыми кислотами и торфом (рис. 2). Кислотность контактирующих растворов варьировали в широком интервале, поскольку, хотя сильнокислые растворы и распространены в большой мере на производстве (к примеру, отработанные катализаторы), значительное место занимают и выдержанные растворы благородных металлов, в которых наблюдаются процессы образования аква- и гидроксокомплексов именно в слабокислой и нейтральной средах.

Как видно из рисунка 2, сорбция Аu (III) в кислой среде с ростом рН возрастает, достигая максимального значения при рН 3 и оставаясь постоянным до рН 5-6 для торфа и до рН 10 для ГК. Степень извлечения золота при оптимальной кислотности составляет 99,9\%. С дальнейшим ростом рН величина сорбции золота падает, что, вероятно, объясняется амфотерностью $\mathrm{Au}(\mathrm{OH})_{3}$, который в щелочных средах способен образовывать несорбируемые соединения типа $\left[\mathrm{Au}(\mathrm{OH})_{4}\right]^{-}$.

В случае сорбции палладия из растворов с переменной кислотностью кривые степени извлечения представлены S-образными кривыми. Это может быть обусловлено рядом факторов: неоднородностью поверхности органического сорбента, полифункциональностью поверхностных групп, реализацией анионообменного механизма или же механизма комплексообразования, а также изменением формы и заряда палладиевых комплексов с изменением $\mathrm{pH}$, которые будут иметь разную способность к образованию связей с функциональными группами торфа и ГК или механическим окклюдированием взвешенных частиц гидроокиси. Согласно [17], хлоридные комплексы Pd(II) очень склонны к щелочному гидролизу: выделение из раствора труднорастворимых продуктов гидролиза начинается при рН выше 3. 


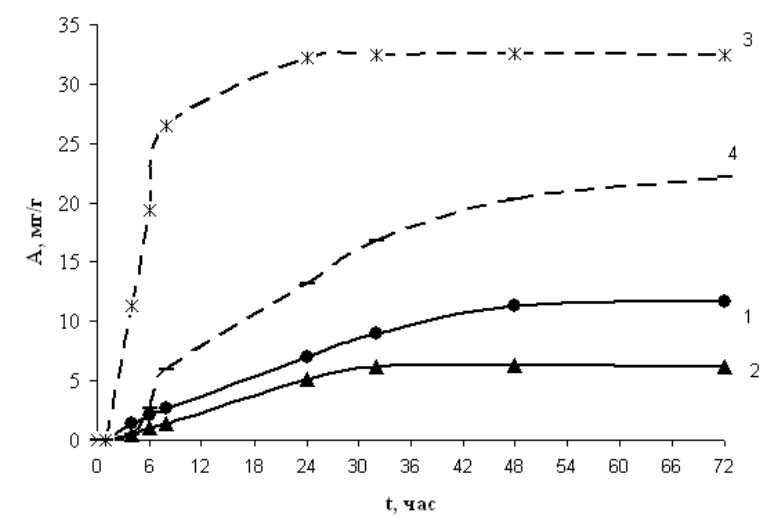

Рис.1. Кинетические кривые сорбции палладия на ГК (1), торф (2) и золота на ГК (3), торф (4).

Концентрация Pd (II) 60 мг/л, Аu (III) 65 мг/л, объем раствора 20 мл, $\mathrm{m}_{\text {сорб. }}=40$ мг

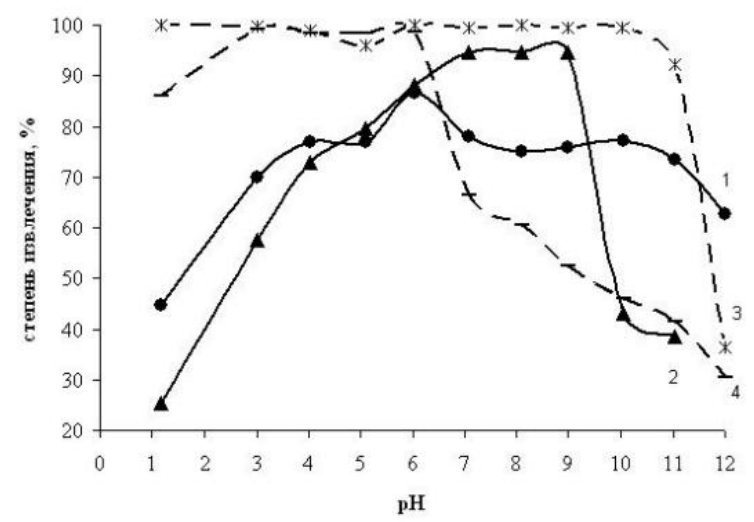

Рис. 2. Степень извлечения палладия и золота в зависимости от рН: 1 - ГК (Pd), 2 -торф (Pd), 3 - ГК (Au), 4 - торф (Au). Концентрация Pd (II) 50 мг/л, $\mathrm{Au}$ (III) 46,1 мг/л, объем раствора 10 мл, $\mathrm{m}_{\text {сорб. }}=20-30 \mathrm{M \Gamma}$

Исследования показали, что оптимальные значения $\mathrm{pH}$, при которых степень извлечения палладия торфом достигает максимального значения - 94,7\%, находятся в интервале от 7 до 9. Максимальная степень извлечения палладия гуминовыми кислотами равна 87 \% при рН, равном 6.

В зависимости от выбранного значения рН модельного раствора поверхность органического сорбента будет приобретать положительный или отрицательный заряд.

При рН 1-3 золото (III) присутствует в виде $\left[\mathrm{AuCl}_{4}\right]^{-},\left[\mathrm{AuCl}_{3} \mathrm{OH}\right]^{-},\left[\mathrm{AuCl}_{4}\left(\mathrm{H}_{2} \mathrm{O}\right)_{2}\right]^{-}$, а палладий (II) в виде $\left[\mathrm{PdCl}_{4}\right]^{2-},\left[\mathrm{Pd}\left(\mathrm{H}_{2} \mathrm{O}\right) \mathrm{Cl}_{3}\right]^{-},\left[\mathrm{Pd}\left(\mathrm{H}_{2} \mathrm{O}\right)_{2} \mathrm{OH}\right]^{+}$и $\left[\mathrm{Pd}\left(\mathrm{H}_{2} \mathrm{O}\right)_{2}(\mathrm{OH})_{2}\right]$. В данном диапазоне рН наблюдается эффект электростатического отталкивания положительно заряженной поверхности сорбента и нейтральных или положительно заряженных комплексов палладия и притягивания отрицательно заряженных комплексов золота, что и обуславливает более низкую сорбцию палладия (II) по сравнению с золотом (III) в кислой среде. При повышении рН поверхность приобретает отрицательный заряд и электростатическое притяжение между отрицательно заряженной поверхностью сорбента и комплексами палладия повышается, что облегчает процесс сорбции.

В процессе адсорбции золота (III) и $\mathrm{Pd}$ (II) происходило изменение $\mathrm{pH}$ растворов (табл. 2).

Так, после сорбции $\mathrm{H}_{2}\left[\mathrm{PdCl}_{4}\right]$ ГК и торфом при $\mathrm{pH}$ 1,18 происходит незначительное подщелачивание раствора на 0,18-0,23 единицы $\mathrm{pH}$. Это можно объяснить адсорбцией $\mathrm{Cl}^{-},\left[\mathrm{Pd}\left(\mathrm{H}_{2} \mathrm{O}\right) \mathrm{Cl}_{3}\right]^{-}$по электрохимическому механизму. Для всех остальных опытов в результате адсорбции величина рН раствора сдвигается в кислую область, и одной из причин этого может быть обмен ионов металла с водородом карбоксильной группы.

Таблица 2. Влияние сорбции на $\mathrm{pH}$ растворов $\mathrm{H}\left[\mathrm{AuCl}_{4}\right]$ и $\mathrm{H}_{2}\left[\mathrm{PdCl}_{4}\right]$

\begin{tabular}{|c|c|c|c|c|c|}
\hline \multicolumn{3}{|c|}{ золото (III) } & \multicolumn{3}{|c|}{ палладий (II) } \\
\hline \multirow{2}{*}{$\begin{array}{c}\mathrm{pH} \text { исходного } \\
\text { раствора } \mathrm{H}\left[\mathrm{AuCl}_{4}\right]\end{array}$} & \multicolumn{2}{|c|}{ рН раствора после сорбции } & \multirow{2}{*}{$\begin{array}{c}\mathrm{pH} \text { исходного рас- } \\
\text { твора } \mathrm{H}_{2}\left[\mathrm{PdCl}_{4}\right]\end{array}$} & \multicolumn{2}{|c|}{ рН раствора после сорбции } \\
\hline & $\Gamma \kappa$ & торф & & $\Gamma K$ & торф \\
\hline 1,30 & 1,21 & 1,13 & 1,18 & 1,36 & 1,41 \\
\hline 3,02 & 2,74 & 2,77 & 3,01 & 2,91 & 2,93 \\
\hline 4,01 & 3,09 & 3,38 & 4,01 & 3,19 & 3,43 \\
\hline 5,01 & 3,3 & 3,76 & 5,11 & 3,24 & 4,01 \\
\hline 6,00 & 4,11 & 4,61 & 6,05 & 3,75 & 4,33 \\
\hline 7,02 & 4,76 & 6,15 & 7,09 & нет данных & 6,41 \\
\hline 8,03 & 4,95 & 6,41 & 8,11 & 6,04 & 6,74 \\
\hline 9,00 & 5,35 & 6,68 & 9,00 & 6,55 & 7,11 \\
\hline 10,00 & 6,03 & 7,45 & 10,04 & 6,80 & 7,34 \\
\hline 11,01 & 6,83 & 7,85 & 11,03 & 8,25 & 8,12 \\
\hline 12,00 & 10,23 & 9,6 & 12,00 & 10,06 & 10,68 \\
\hline
\end{tabular}


Таким образом, на основании экспериментов по сорбционному концентрированию золота и палладия было установлено, что ГК и торф извлекают палладий из хлоридных растворов на уровне 87-95\% при оптимальной кислотности раствора, золото - 99,9\%. Для всех сорбентов с уменьшением кислотности среды увеличивается степень извлечения благородных металлов, достигающая максимального значения в слабощелочной области $\mathrm{pH}$, а затем снижающаяся практически до исходного значения. Вероятно, уменьшение кислотности среды приводит к возрастанию конкуренции между комплексными анионами палладия и золота и хлорид-ионами в процессе ионного обмена. В щелочной среде, возможно, происходит образование $\left[\mathrm{Pd}(\mathrm{OH})_{4}\right]^{2-},\left[\mathrm{Au}(\mathrm{OH})_{4}\right]^{-}$т.е. координационно-насыщенных анионов, неспособных к образованию мостиковых связей с сорбентом в щелочной среде.

Для установления механизма сорбционного концентрирования палладия и золота были сняты ИКспектры этих сорбентов в исходной форме и после насыщения их из растворов металлами (рис. 3). ИКспектрометрия принадлежит к числу методов, позволяющих оценить структурные особенности вещества, установить присутствие важнейших групп атомов, радикалов и типов связей, характерных функциональных групп.

Изучаемые органические сорбенты содержат большой набор разнообразных атомных группировок, поэтому полосы поглощения часто составные, широкие и обусловлены колебаниями различных групп, вследствие этого положения максимумов могут быть промежуточными между максимумами составляющих компонентов. Минеральные компоненты дают собственные полосы поглощения в тех же областях, что и гуминовые кислоты [15].

Из рисунка 3 следует, что на ИК-спектрах гуминовых кислот имеется широкая интенсивная полоса поглощения с четко выраженным максимумом при 3395-3388 см-1, обусловленная валентными колебаниями ОН групп различного характера, связанными преимущественно межмолекулярными водородными связями. Перегиб на крыле этой полосы около $3100 \mathrm{~cm}^{-1}$ отвечает валентным колебаниям N-H в структуре амида и аминов, связанных водородными связями.. Дуплет средней интенсивности при 2925 и 2853 см$^{-1}$ относят к валентным колебаниям $-\mathrm{CH}_{2}-$ и $-\mathrm{CH}_{3}$ групп боковых цепей в молекулах ГК, но преимущество отдают метиленовым группировкам. Асимметричные и симметричные деформационные колебания связи $\mathrm{C}-\mathrm{H}$ в $-\mathrm{CH}_{2}-$ и $-\mathrm{CH}_{3}$ группах проявляются в слабовыраженных максимумах при 1460 и $1377 \mathrm{~cm}^{-1}$.

В ИК-спектрах ГК отмечается слабое поглощение при 2600-2500 см-1, которое характерно для карбоновых кислот. Эта широкая полоса считается очень характерной для валентных колебаний гидроксильных групп, участвующих в образовании сильных водородных связей в димерных формах карбоновых кислот. Валентные колебания карбонильной группы, которая может быть представлена кетонами, альдегидами, карбоно-

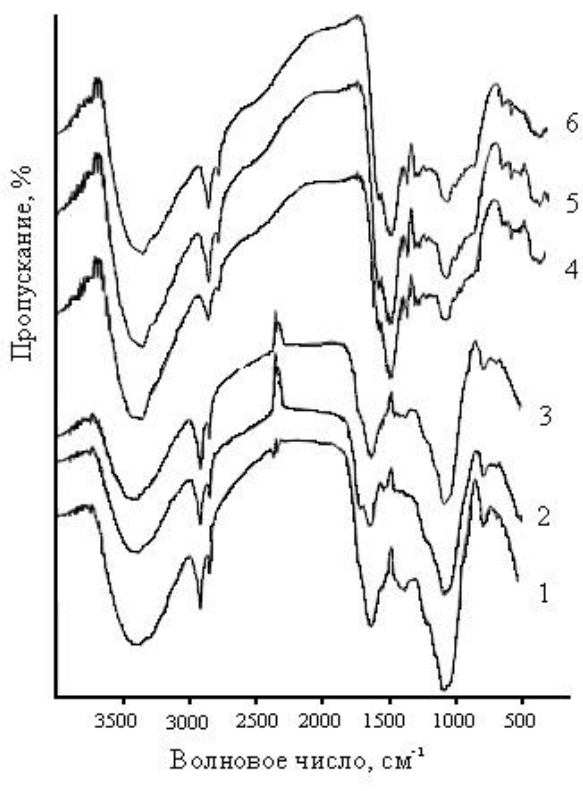

Рис. 3. ИК-спектры пропускания: 1 - торф; 2 - торф+Au; 3 - торф+Pd; $4-\Gamma К ; 5-\Gamma К+\mathrm{Au} ; 6-\Gamma К+\mathrm{Pd}$ выми кислотами и их функциональными производными, характеризуются полосой пропускания с частотой $1720 \mathrm{~cm}^{-1}$. При образовании солей гуминовых кислот эта полоса должна уменьшиться, а вместо нее должны появиться две характерные полосы карбоксилат-иона при 1590 и $1390 \mathrm{~cm}^{-1}$ [15]. Следует отметить, что после сорбции золота и палладия уменьшения п.п. $1720 \mathrm{~cm}^{-1}$ не наблюдалось.

Интенсивная полоса с максимумом поглощения при $1638 \mathrm{~cm}^{-1}$ обусловлена плоскостными колебаниями сопряженных углерод-углеродных (ароматические) и углеродкислородных связей (карбонилы, связанные водородными связями, карбоксилат-ионы), в ароматическом скелете и хинонах [18]. Слабые полосы поглощения при $1564 \mathrm{~cm}^{-1}$ отнесены к С-С связям пиррола, а при 1543 см$^{-1}$ к деформационным колебания амидной группы [19]. Полоса поглощения около $1511 \mathrm{~cm}^{-1}$ указывает на наличие неконденсированных ароматических соединений в составе ГК, связанных с атомами азота и кислорода. Полоса поглощения с максимумом при 1237 $1223 \mathrm{~cm}^{-1}$ характеризует деформационные колебания атомов карбоксильной группы. Поглощения в области $1127 \mathrm{~cm}^{-1}$ определяются в основном валентными и деформационными 
колебаниями О-Н групп в спиртах и карбоновых кислотах. Слабые полосы поглощения при 1077-1083 и 1036-1040 см ${ }^{-1}$ отнесены к антисимметричным валентным колебаниям внутри тетраэдров $\mathrm{Si}-\mathrm{O}_{4}$.

В области волновых чисел от 850 до $694 \mathrm{~cm}^{-1}$ наблюдаются слабые полосы поглощения, возможно обусловленные внеплоскостными деформационными колебаниями в ароматических кольцах, имеющих два и более незамещенных атомов водорода. Таким образом, максимальная интенсивность полос поглощения в спектрах ГК низинного торфа отмечена для гидроксильных, карбонильных групп, алифатических и ароматических фрагментов.

ИК-спектры образцов торфа имеют существенные отличия: не выявлены полосы поглощения, относящиеся к деформационным колебаниям атомов карбоксильной группы $\left(1237 \mathrm{~cm}^{-1}\right)$ и деформационным колебаниям ОН групп в спиртах и карбоновых кислотах $\left(1127 \mathrm{~cm}^{-1}\right)$, выявились интенсивные полосы поглощения с максимумом при 1090 и $797 \mathrm{~cm}^{-1}$, относящиеся к валентным колебаниям внутри и по внешним связям тетраэдра $\mathrm{SiO}_{4}$ соответственно и полоса поглощения с максимумом при $2347 \mathrm{~cm}^{-1}$, отнесенная к валентным колебаниям $-\mathrm{NH}_{2}$ и $-\mathrm{C} \equiv \mathrm{N}$ групп.

По положению основных полос ИК-спектры исходных сорбентов и сорбентов с нанесенным золотом и палладием мало отличаются (рис. 3). Только происходит сдвиг полосы поглощения с максимумом при $1237 \mathrm{~cm}^{-}{ }^{1}$, связанной с группой - $\mathrm{COOH} \mathrm{на} 13 \mathrm{~cm}^{-1}$ для ГК+Рd в длинноволновую область, что свидетельствует о том, что для всех образцов, за исключением ГК+ Рd, способ закрепления благородных металлов одинаков.

Следует отметить, что при проведении сорбции ионного золота на ГК наблюдалось формирование частиц коллоидного золота (цвет раствора становился фиолетово-бордовый) как в кислых, так и в щелочных средах. Однако полосы поглощения связей $\mathrm{Au}-\mathrm{Au}$ и $\mathrm{Pd}-\mathrm{Pd}$ в ИК-спектрах не были обнаружены вследствие того, что колебания связи Ме-Ме не активны в диапазоне частот 400-4000 $\mathrm{cm}^{-1}$ [20].

Результаты сканирующей электронной микроскопии являются достаточно объективным подтверждением существования золота на ГК и торфе в виде частиц элементарного золота. Методом электронной микроскопии показано, что в образцах торфа и в осадке ГК присутствовали наночастицы золота (рис. 4).

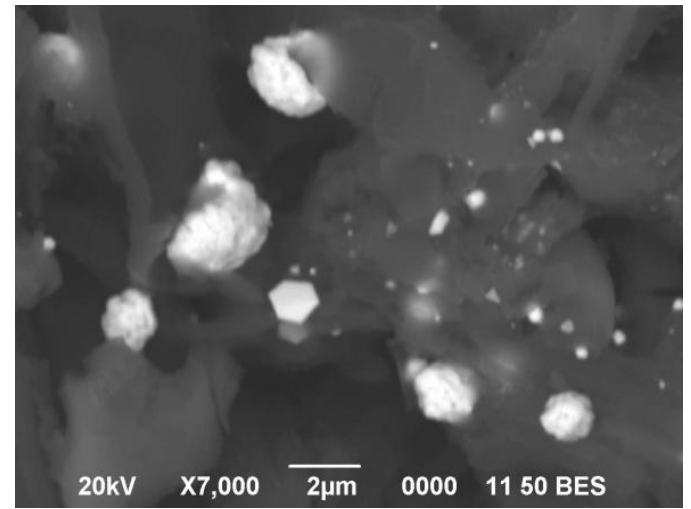

a

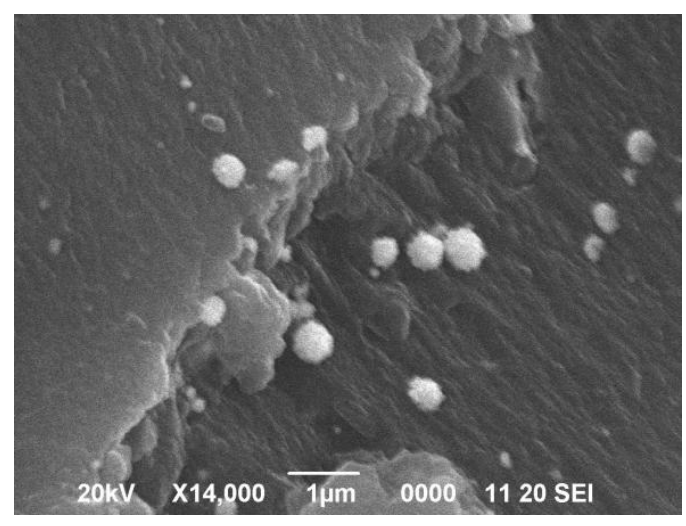

B

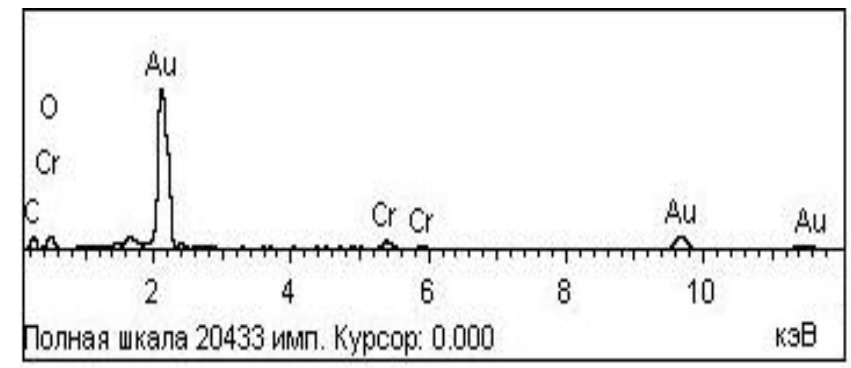

б

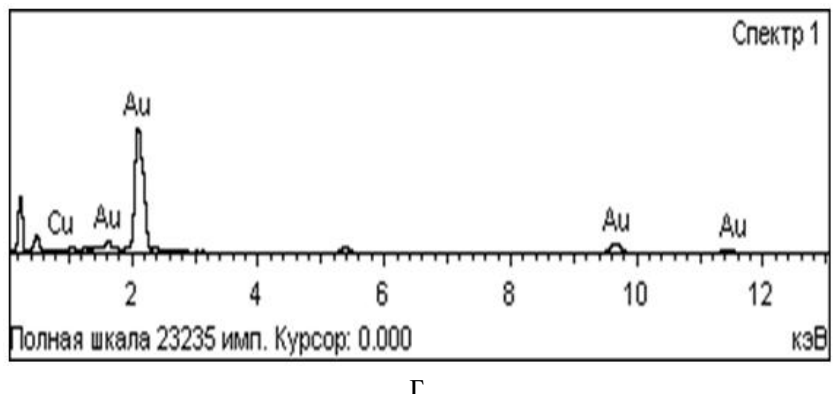

$\Gamma$

Рис. 4. Кластеры шаровидных сложных агрегатов наночастиц золота и элементный состав наночастиц золота на торфе (а, б) и ГК (в, г) 
Отмечена неравномерность распределения наночастиц золота на поверхности зерен сорбента. Избирательность этого процесса проявляется в преимущественной локализации золота на более углеродистых фрагментах структурно неоднородной подложки. Средний размер наночастиц золота составляет 0,2 мкм. Разрозненные «одинокие» зерна золота размером 1-3 мкм встречались довольно редко. По составу исследованные на торфе и ГК металлические зерна представлены преимущественно золотом с низкой примесью $\mathrm{Cu}$ (до 1-2 мас. \%).

Таким образом, при аккумуляции золота гуминовыми кислотами и торфом может происходить восстановление ионного золота органической матрицей до элементного нанодисперсного состояния.

При сорбции палладия на торф также наблюдалось восстановление палладия. На электронных фотографиях (рис. 5) видно, что доминируют наночастицы палладия размером менее 0,2 мкм.

Для ГК методом электронной микроскопии установлено распределение палладия по всей поверхности, однако восстановленных форм палладия не обнаружено. Этот факт свидетельствует о том, что взаимодействие ГК с растворами палладия останавливается на стадии сорбции, что подтверждается и данными ИК-спектроскопии.

Сопоставление экспериментальных данных по сорбции благородных металлов органическими сорбентами с данными об их состоянии в водных растворах, приводит к выводу о существовании сложного механизма сорбции для указанных систем. Вероятно, на первой стадии происходит ионный обмен, на второй - внедрение атомов функциональных групп сорбента во внутреннюю сферу комплекса благородного металла. По этой причине равновесие сорбции устанавливается в течение длительного времени и наночастицы восстановленных золота и палладия содержат примеси других металлов, в частности меди. Процесс взаимодействия благородных металлов с органическими сорбентами не останавливается на стадии сорбции, а продолжается до восстановления металлов в виде наноразмерных частиц, образующих в дальнейшем агрегаты.
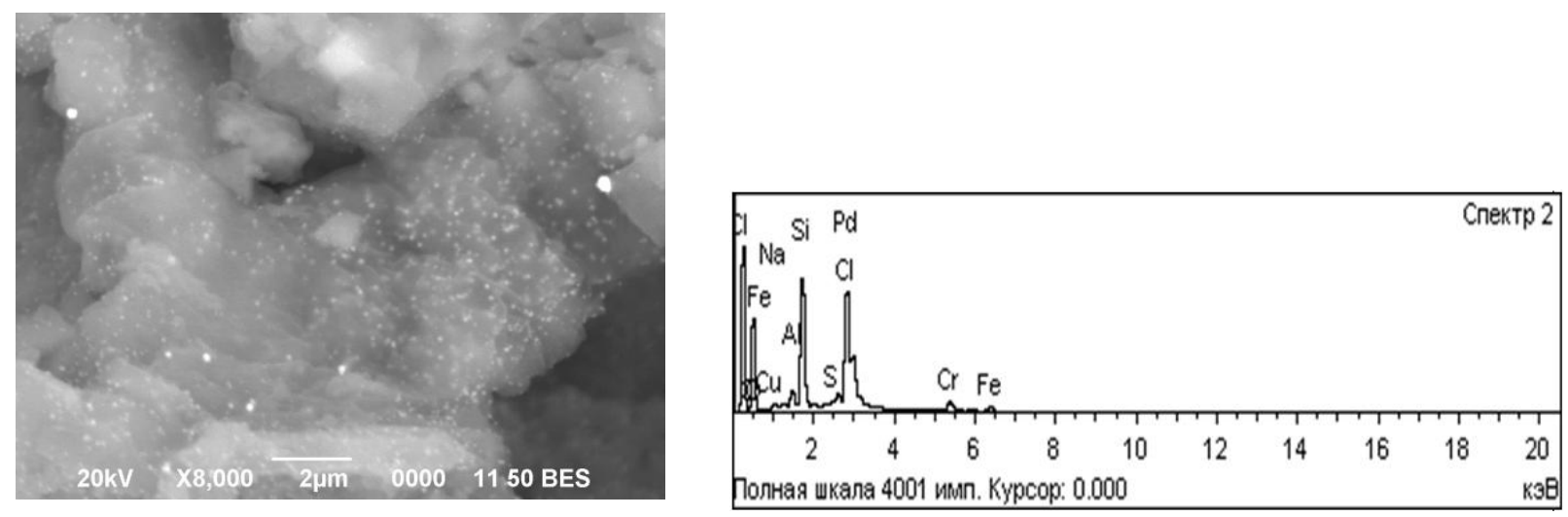

Рис. 5. Фрагмент поверхности торфа с наночастицами палладия и элементный состав наночастиц

\section{Bыbodbl}

На основании экспериментов по сорбционному концентрированию благородных металлов было установлено, что торф извлекает золото из хлоридных растворов на уровне 99,9\% при рН 3-6, а гуминовые кислоты - в области $\mathrm{pH}$ 3-10. Палладий эти сорбенты извлекают хуже: максимальная сорбция Рd гуминовой кислотой, равная 87\%, наблюдалась при рН 6. Степень извлечения палладия 95\% торфом достигалась при pH 7-9.

Процесс сорбции золота и палладия торфом и ГК имеет сложный механизм. Предположено, что на первой стадии происходит ионный обмен, на второй - внедрение атомов функциональных групп сорбента во внутреннюю сферу комплекса благородного металла. Показано, что при взаимодействии золота с поверхностью торфа и гуминовых кислот, палладия с торфом происходит восстановление ионных форм благородных металлов до элементного состояния. Взаимодействие гуминовых кислот с растворами палладия останавливается на стадии сорбции. 


\section{Список литературы}

1. Варшал Г.М., Велиханова Т.К., Корочанцев А.В., Тобелко К.И., Галузинская А.Х., Ахманова М.В. О связи сорбционной емкости углеродистого вещества пород по отношению к благородным металлам с его структурой // Геохимия. 1995. №8. С. 1191-1198.

2. Носкова Л.П. Гуминовые вещества бурого угля Сергеевского месторождения // Химия в интересах устойчивого развития. 2009. Т. 17. С. 61-65.

3. Варшал Г.М., Кощеева И.Я., Велюханова Т.К., Чхетия Д.Н., Тютюнник О.А., Гриневская Ж.М. Сорбция тяжелых металлов и изотопных носителей долгоживущих радионуклидов на гуминовой кислоте: сообщение I. Сорбция цезия (I), стронция (II), церия (III), рутения (IV) на гуминовой кислоте // Геохимия. 1996. №11. C. $1107-1112$.

4. Будаева А.Д., Золтоев Е.В., Тихова В.Д., Бодоев Н.В. Взаимодействие ионов тяжелых металлов с гуматами аммония // Журнал прикладной химии. 2006. Т. 79, вып. 6. С. 930-933.

5. Радомский С.М., Радомская В.И., Моисеенко Н.В., Моисеенко В.Г. Наночастицы благородных металлов в торфе Верхнего и Среднего Приамурья // Доклады Академии наук. 2009. Т. 426, №2. С. $232-234$.

6. Семенова 3.В., Носкова Л.П. Гидрогенолиз сапропелита // Химия твердого топлива. 1994. №4-5. С. 128-135.

7. Kuimova N.G., Pavlova L.M., Radomskaya V.I. Biogenic Concentration of Noble Metals // Georesources. 2012. N1(12). Pp. 21-24.

8. Куимова Н.Г., Радомская В.И., Павлова Л.М. Концентрирование палладия на геохимических барьерах // Горный информационно-аналитический бюллетень. 2012. №9. С. 77-84.

9. Буслаева Т.М., Симанова С.А. Состояние платиновых металлов в солянокислых и хлоридных водных растворах. Палладий, платина, родий, иридий // Координационная химия. 1999. Т. 25, №3. С. 165-176.

10. Симонов П.А., Троицкий С.Ю., Лихолобов В.А. Приготовление катализаторов Pd/C: исследование процессов формирования активных центров на молекулярном уровне // Кинетика и катализ. 2000. Т. 41, №2. С. 281-297.

11. Королева Л.А., Шикина Н.Д., Колодина П.Г., Зотов А.В., Тагиров Б.Р., Шваров Ю.В., Волченкова В.А., Шаззо Ю.К. Экспериментальное изучение гидролиза палладия в водных растворах при 25-70 ${ }^{\circ} \mathrm{C} / /$ Геохимия. 2012. №10. С. 949-956.

12. Миронов И.В., Макотченко Е.В. Равновесия в системе хлороаквагидроксокомплексов золота (III) в водном растворе // Журнал неорганической химии. 2009. Т. 54, №12. С. 2091-2099.

13. Бусев А.И., Иванов В.М. Аналитическая химия золота. М., 1973. 263 с.

14. Радомская В.И., Лосева О.В., Радомский С.М. Применение тиомочевины для концентрирования золота из вторичного сырья // Вестник Дальневосточного отделения Российской академии наук. 2004. №1. С. 80-86.

15. Орлов Д.С. Гумусовые кислоты почв и общая теория гумификации. М., 1990. 325 с.

16. Гиндин Л.М. Экстракционные процессы и их применение. М., 1984. 144 с.

17. Печенок С.И. Сорбционно-гидролитическое осаждение платиновых металлов на поверхности неорганических сорбентов. Л., 1991. 248 с.

18. Белоусов М.В., Ахмеджанов Р.Р., Гостищева М.В., Юсубов М.С., Матвеенко А.В. Исследование химических и токсических свойств гуминовых кислот низинного древесно-травяного торфа Томской области // Бюллетень сибирской медицины. 2009. №4 (2). С. 27-33.

19. Маликов Д.А., Горяченкова Т.А., Новиков А.П., Трейтяк Р.З Сорбция актинидов химически модифицированными гуминовыми кислотами // Геохимия. 2012. №12. С. 1147-1153.

20. Астапова Е.С., Радомский В.С., Коробицина Л.Л., Филимонов А.В. Интерпретация структуры цеолитов, модифицированных наночастицами, с помощью ИК-спектроскопии // Научно-технические ведомости СанктПетербурского государственного политехнического университета. Физико-математические науки. 2010. №3. C. 53-58. 
Radomskaya V.I. ${ }^{1 *}$, Pavlova L.M. ${ }^{1}$, Noskova L.P. ${ }^{l}$, Kotelnikov V.Yu. ${ }^{2}$, Ivanov V.V. ${ }^{3}$, Poselyuzhnaya A.V. ${ }^{3}$ SORPTION PROPERTIES OF PEAT AND HUMIC ACIDS TOWARDS PRECIOUS METALS

${ }^{1}$ Institute of Geology and Nature Management Far Eastern Branch Russian Academy of Sciences; Relochniy line 1,

Blagoveshchensk, 675000, (Russia)

e-mail: radomskaya@ascnet.ru

${ }^{2}$ Criminal Expertise Centre of Amurskyi Regional Office of the Ministry of Internal Affairs of Russia; Batareinaya st. 30 a, Blagoveshchensk, 675000, (Russia)

${ }^{3}$ Geological Institute, Far Eastern Branch of Russian Academy of Sciences; Vladivostok's 100-years avenue 159,

Vladivostok, 690022 (Russia)

Experimental investigations of gold and palladium sorption by peat and humic acids are executed. Results of researches displayed the high sorption possibility of extraction precious metals by natural sorbents. At interaction of gold solutions with pear and humic acids surface, palladium interaction with peat, there is a precious metals restoration within the formation of nanoparticles on its surface. Humic acids interaction with palladium solutions stops at a sorption stage.

Keywords: peat, humic acids, sorption, restoration, gold nanoparticles, palladium.

\section{References}

1. Varshal G.M., Velikhanova T.K., Korochantsev A.V., Tobelko K.I., Galuzinskaia A.Kh., Akhmanova M.V. Geokhimiia, 1995, no. 8, pp. 1191-1198. (in Russ.).

2. Noskova L.P. Khimiia v interesakh ustoichivogo razvitiia, 2009, vol. 17, pp. 61-65. (in Russ.).

3. Varshal G.M., Koshcheeva I.Ia., Veliukhanova T.K., Chkhetiia D.N., Tiutiunnik O.A., Grinevskaia Zh.M. Geokhimiia, 1996, no. 11, pp. 1107-1112. (in Russ.).

4. Budaeva A.D., Zoltoev E.V., Tikhova V.D., Bodoev N.V. Zhurnal prikladnoi khimii, 2006, vol. 79, no. 6, pp. 930-933. (in Russ.).

5. Radomskii S.M., Radomskaia V.I., Moiseenko N.V., Moiseenko V.G. Doklady Akademii nauk, 2009, vol. 426, no. 2, pp. 232-234. (in Russ.).

6. Semenova Z.V., Noskova L.P. Khimiia tverdogo topliva, 1994, no. 4-5, pp. 128-135. (in Russ.).

7. Kuimova N.G., Pavlova L.M., Radomskaya V.I. Georesources, 2012, no. 1(12), pp. 21-24.

8. Kuimova N.G., Radomskaia V.I., Pavlova L.M. Gornyi informatsionno-analiticheskii biulleten', 2012, no. 9, pp. $77-84$. (in Russ.).

9. Buslaeva T.M., Simanova S.A. Koordinatsionnaia khimiia, 1999, vol. 25, no. 3, pp. 165-176. (in Russ.).

10. Simonov P.A., Troitskii S.Iu., Likholobov V.A. Kinetika i kataliz, 2000, vol. 41, no. 2, pp. 281-297. (in Russ.).

11. Koroleva L.A., Shikina N.D., Kolodina P.G., Zotov A.V., Tagirov B.R., Shvarov Iu.V., Volchenkova V.A., Shazzo Iu.K. Geokhimiia, 2012, no. 10, pp. 949-956. (in Russ.).

12. Mironov I.V., Makotchenko E.V. Zhurnal neorganicheskoi khimii, 2009, vol. 54, no. 12, pp. 2091-2099. (in Russ.).

13. Busev A.I., Ivanov V.M. Analiticheskaia khimiia zolota. [Analytical chemistry of gold]. Moscow, 1973, 263 p. (in Russ.).

14. Radomskaia V.I., Loseva O.V., Radomskii S.M. Vestnik Dal'nevostochnogo otdeleniia Rossiiskoi akademii nauk, 2004, no. 1, pp. 80-86. (in Russ.).

15. Orlov D.S. Gumusovye kisloty pochv $i$ obshchaia teoriia gumifikatsii. [Humic acid soils and the general theory of humification]. Moscow, 1990, 325 p. (in Russ.).

16. Gindin L.M. Ekstraktsionnye protsessy i ikh primenenie. [Extraction processes and their application]. Moscow, 1984, 144 pc. (in Russ.).

17. Pechenok S.I. Sorbtsionno-gidroliticheskoe osazhdenie platinovykh metallov na poverkhnosti neorganicheskikh sorbentov. [Sorption-hydrolytic precipitation of platinum metals on the surface of inorganic sorbents]. Leningrad, 1991, 248 p. (in Russ.).

18. Belousov M.V., Akhmedzhanov R.R., Gostishcheva M.V., Iusubov M.S., Matveenko A.V. Biulleten' sibirskoi meditsiny, 2009, no. 4(2), pp. 27-33. (in Russ.).

19. Malikov D.A., Goriachenkova T.A., Novikov A.P., Treitiak R.Z. Geokhimiia, 2012, no. 12, pp. 1147-1153. (in Russ.).

20. Astapova E.S., Radomskii V.S., Korobitsina L.L., Filimonov A.V. Nauchno-tekhnicheskie vedomosti SanktPeterburskogo gosudarstvennogo politekhnicheskogo universiteta. Fiziko-matematicheskie nauki, 2010, no. 3, pp. 53-58. (in Russ.). 